\title{
THE NERVOUS CONTROL OF LUMINESCENT RESPONSES IN POLYNOID WORMS
}

\author{
By J. A. C. Nicol \\ The Plymouth Laboratory
}

(Text-figs. I-IO)

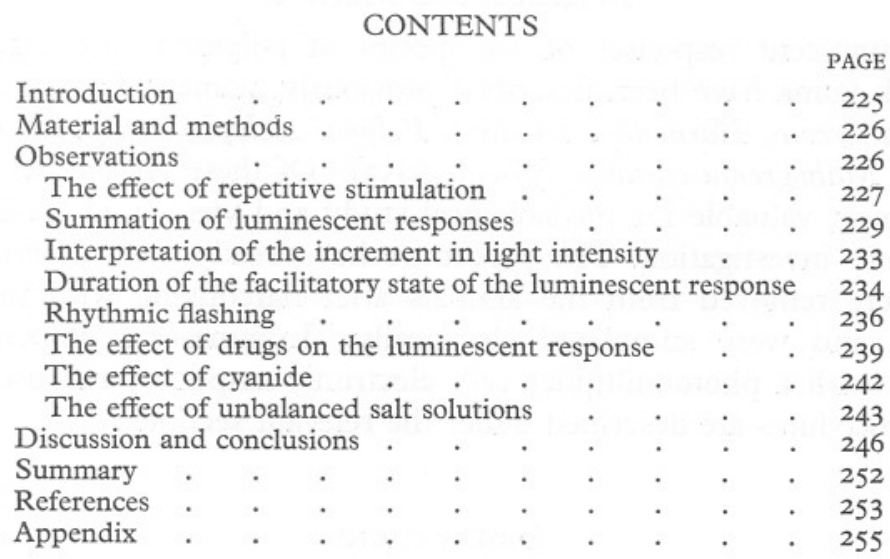

\section{INTRODUCTION}

Some preliminary observations on luminescence in polynoid worms have been presented in a previous paper (Nicol, 1953). These animals produce light in scales (elytra) which cover the dorsal surface of the body. The source of the light lies in a layer of unicellular epithelium on the lower surface of the scale. Histologically, this tissue consists of columnar cells (photocytes), characterized by the presence of coarse eosinophilic granules in the cytoplasm. The nervous supply of the elytrum derives from a nerve trunk which ascends the stalk or elytrophore and proceeds to a ganglion in the centre of the scale. From this ganglion nerves radiate peripherally and proceed to the photocytes, and to sensory receptors on the dorsal surface and at the margin of the scale (Bonhomme, 1942).

The normal response of a scale consists of a series of brief flashes, each about $80 \mathrm{msec}$. in duration, which appear over the entire photogenic area of the scale. The flashes usually start at a frequency of about $9 / \mathrm{sec}$., but the rate soon falls off to about $\mathrm{I} / \mathrm{sec}$., and is sometimes maintained for a minute. In rhythmic flashing of this pattern it is observed that the first few flashes gradually build up to maximal intensity, and then fall off in height. This 
progressive decrease in intensity of consecutive flashes is due to gradual exhaustion of luminescent material, and if the response proceeds long enough, the flashes ultimately become very weak, or disappear. When the response stops short of complete exhaustion, progressive fatigue can be produced by repeating the stimulation at suitable intervals.

Owing to the quick and repetitive character of the flashes, it has been possible to secure considerable quantitative data for physiological analysis of the response mechanism, which will be considered in the present paper.

\section{Material AND Methods}

The luminescent responses of six species of polynoids occurring in the Plymouth fauna have been described previously, namely Lagisca extenuata, Gattyana cirrosa, Harmothoë lunulata, Polynoë scolopendrina, Acholoë astericola and Malmgrenia castanea (Nicol, I953). Of these Acholoë and Polynö̈ proved most valuable for physiological study and were used extensively in the present investigation. The procedure has already been described. The scales were removed from the animals after narcotizing with magnesium chloride, and were stimulated electrically. Luminescent responses were recorded with a photomultiplier cell, electronic amplifier, and oscilloscope. Other procedures are described under the relevant sections.

\section{OBSERVATIONS}

The quick flashes which can be obtained by electrical stimulation of the scale are not affected in magnitude by variations in the strength of the stimulus. In scales which tend to flash rhythmically it has been found that a gradual increase in voltage has no effect until threshold is reached, when the scale starts to flash repeatedly at light intensities quickly rising to a maximum. Since such a response leads to exhaustion, it cannot be repeated in the same scale for the study of the effects of subsequent stimuli. Apparently, however, there is no gradual increment in response according to the strength of stimulus, but rather a maximal outburst when the effective strength is reached.

Although rhythmic flashing is the usual response to a single shock, occasionally an elytrum gives only a single flash to one stimulus. This is observed in elytra which have been stimulated previously by electric shocks and in some way fatigued, and also occurs in some elytra which have not yet been subjected to electrical stimulation. These latter preparations may well be from animals which have been excited during collecting and handling, or in which the elytral ganglion has been injured. It is difficult, however, to avoid contingencies of this kind. Preparations which will give only one flash per stimulus can also be secured by removal of the ganglion. This is described in a later section. 
With scales that respond by a single flash to a stimulus it has been observed that once threshold is reached, further increase in stimulus strength brings about no increment in the intensity of the quick flash. This result is in agreement with the conclusion previously reached, that the luminescent flashes are produced by nervous stimulation, for excitation of the efferent nerve fibres is an all-or-nothing phenomenon.

When the stimulus strength is raised greatly, or the pulse duration is increased, a second type of response is obtained. This takes the form of a bright, prolonged glow, which quickly rises to a peak in about $\frac{1}{2} \mathrm{sec}$., and lasts up to Io sec. (Fig. IA). Such a response frequently leads to complete exhaustion of the photogenic material contained in the scale, and subsequent stimuli are ineffective. In some preparations a pattern of rhythmic flashing is superimposed on the bright glow, or can be induced by repetitive stimulation (Fig. I B). It is concluded that in this type of response, partial or complete depolarization of the photocytes is achieved by direct stimulation of the latter, and that the effect of nervous impulses may intervene and influence the primary response. When scales which are being strongly stimulated are watched under the microscope it can be seen that the entire photogenic area lights up with a bright prolonged glow, or part of it does so, and rhythmic flashes proceed peripherally from a central glowing region. In the latter event only part of the photogenic area has been excited directly, and nervous stimulation is affecting the remainder of the photogenic field. For experimental purposes the strength of stimulation has been kept at a minimum in order to avoid direct excitation of the luminescent cells, but a certain amount of direct depolarization appears in a few of the records.

\section{The Effect of Repetitive Stimulation}

By using scales which respond initially by a single flash to a shock it is possible to analyse the effects of repetitive stimulation.

Single flash responses, one per stimulus, are illustrated in Fig. I C-E (Acholö̈). The experiment recorded in Fig. I C, D will be considered in detail. It will be noticed that the overt responses to the first two stimuli (time interval $6 \mathrm{sec}$.) are barely perceptible (direct depolarization), but the response to the third stimulus is a definite flash. Continued stimulation, at a rate of $45 / \mathrm{min}$. (interval $\mathrm{I} \cdot 3 \mathrm{sec}$.) resulted in discrete flashes, one per stimulus, but after the fourth stimulus double flashes appeared, the beginning of repetitive flashing. All subsequent responses to a single stimulus consisted of several flashes. The responses also became much smaller with repetition, as the result of fatigue. A somewhat similar pattern is shown in Fig. IE. Here the response to the first stimulus was small (direct depolarization), the next six responses increased gradually in height, and occasionally there was a tendency for repetitive flashing.

The increase in height of successive responses with repetitive stimulation 
is a noteworthy feature of these records and is documented in Figs. I C-E and 3D and in the accompanying graph (Fig. 2), based on a photographic record.

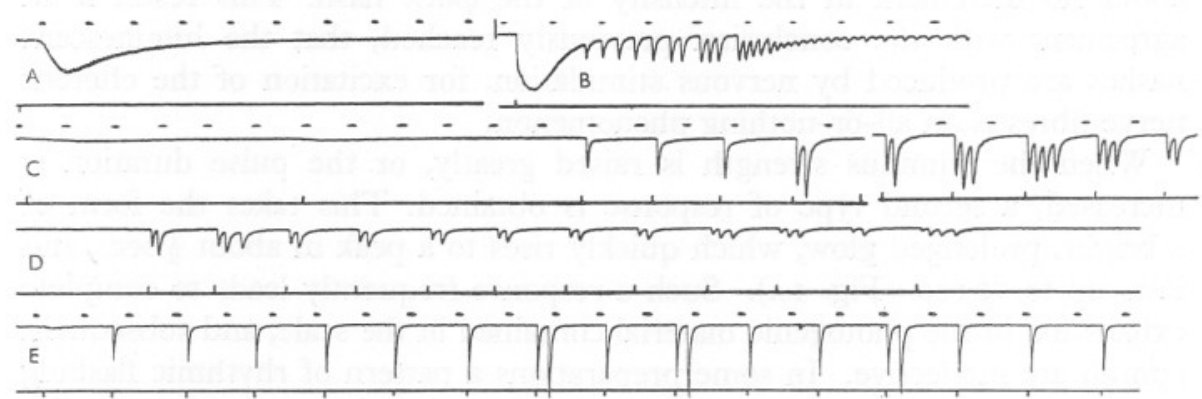

Fig. I. A, protracted luminescent responses (elytrum of Lagisca extenuata), resulting from direct stimulation of the luminescent cells. Time scale, I/sec. Effective stimulus, lower left. B, protracted luminescent response (elytrum of Acholoë astericola), on which are imposed rhythmic flashes after a delay of $\mathrm{I} .8 \mathrm{msec}$. Time scale, I/sec. Effective stimulus, lower left. C, D, single flashes and rhythmic flashing induced in an elytrum of Acholoë by single shocks and repetitive stimulation. Time scale above, I/sec. Stimuli indicated on lower line. E, luminescent responses in an elytrum of Acholoë. Single flashes and repeated flashes induced by repeated shocks at a slow rate of $42 / \mathrm{min}$. Time scale I/sec. Stimuli shown on lower line.



Fig. 2. A plot showing the change in intensity of successive responses in an elytrum of Acholoë stimulated by a burst of impulses at a frequency of $5 / \mathrm{sec}$. Ordinates, light intensities in arbitrary units. Each vertical line represents a separate light flash. Arrow indicates end of stimulation.

Three factors are revealed in these records: (i) the response to the first stimulus may be small, but subsequent stimuli will evoke bright flashes; (ii) repetitive stimulation brings about an increase in the magnitude of 
successive flashes; (iii) finally, repetitive stimulation will evoke the onset of rhythmic flashes or flickering.

The effects obtained with repetitive stimulation can be compared advantageously with the course of events in rhythmic flashes evoked by a single stimulus. In the latter form of response it is also observed that the initial flashes increase in intensity (Nicol, I953). Occasionally, when a stimulus produces only a single flash, two or more stimuli will start the scale flashing, again with progressive increment in light intensity (Fig. 3A-C, Lagisca and Harmothö̈). Changes in the frequency of rhythmical flashing and the intensity of the flashes, however, are distinct phenomena, although the former is capable of influencing the latter.

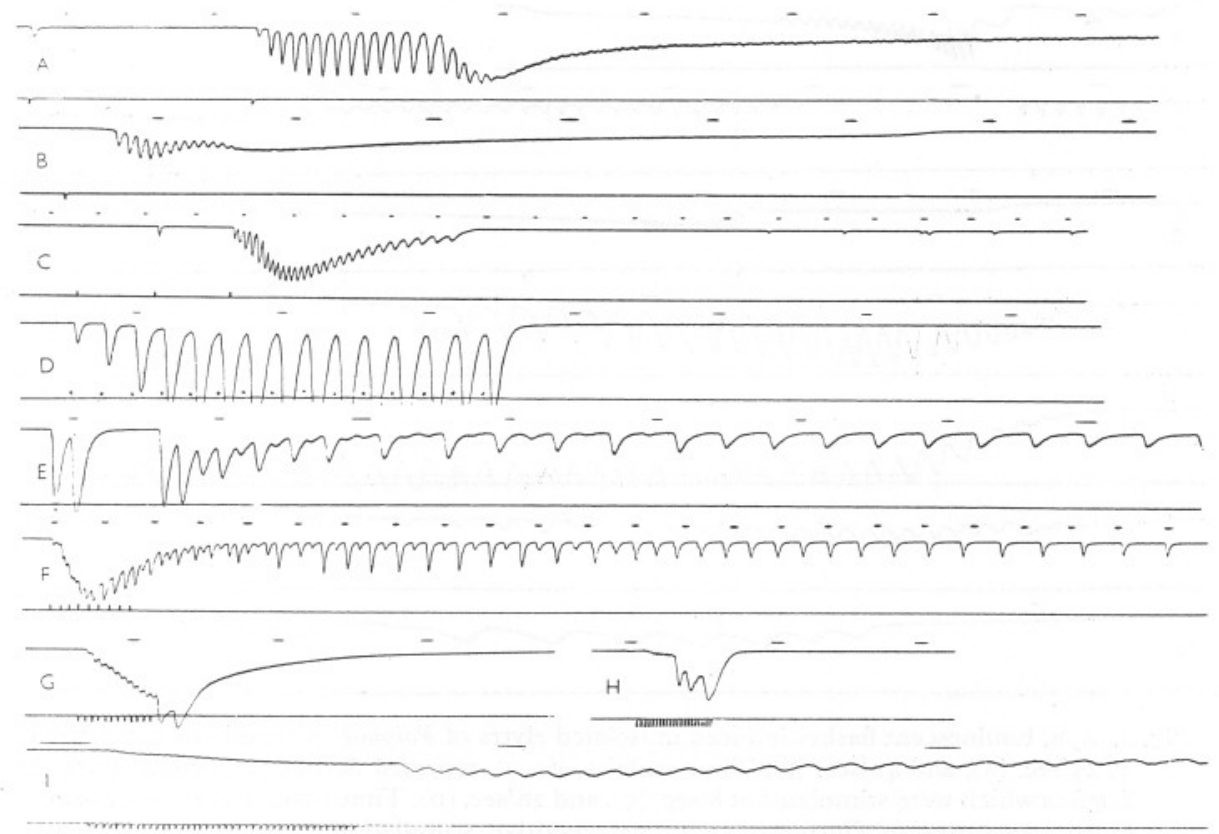

Fig. 3. A, luminescent responses of an elytrum of Lagisca, a rhythmic flashing induced by two consecutive impulses at an interval of $\mathrm{I} .5 \mathrm{sec}$. B, flashing induced by a single stimulus. Time scale $\mathrm{I} / \mathrm{sec}$. Stimuli shown on bottom line. The response in these records terminates in a prolonged glow. c, luminescent responses of an elytrum of Harmothoë lunulata. Repetitive flashing induced by three consecutive stimuli at a frequency of $42 / \mathrm{min}$. Time scale, $\mathrm{I} / \mathrm{sec}$. Stimuli shown on bottom line. D-I, luminescent responses of elytra of Acholoë, stimulated by series of impulses at different frequencies. Time scale above each record, I/sec. Stimuli shown on lower line. Frequencies of stimulation are: $\mathrm{D}, \mathrm{E}, 6 / \mathrm{sec} ., \mathrm{E}$ is a continuation of record $\mathrm{D}$, and shows delayed rhythmic discharge; F, 6/sec.; G, 24/sec.; H, 36/sec.; I, 70/sec.

\section{Summation of Luminescent Responses}

When elytra are stimulated at low frequencies, below $7 /$ sec., separate and distinct flashes are obtained (Figs. IE, 3D, F). At frequencies somewhat 
greater than this the separate flashes begin to fuse together, and the degree of fusion becomes more and more pronounced at higher frequencies. In Acholoë the separate flashes are still perceptible at frequencies of about $25 / \mathrm{sec}$. (Fig. 3G), but are practically erased at frequencies reaching $40 / \mathrm{sec}$. or more (Fig. $3 \mathrm{H}, \mathrm{I}$ ). Similar results were obtained by stimulating isolated scales of Polynö̈ (Fig. 4A, B), Lagisca (Fig. 4C, D), and Gattyana (Fig. 4E-H). Since the time taken to reach maximal intensity in a single flash is in the region of

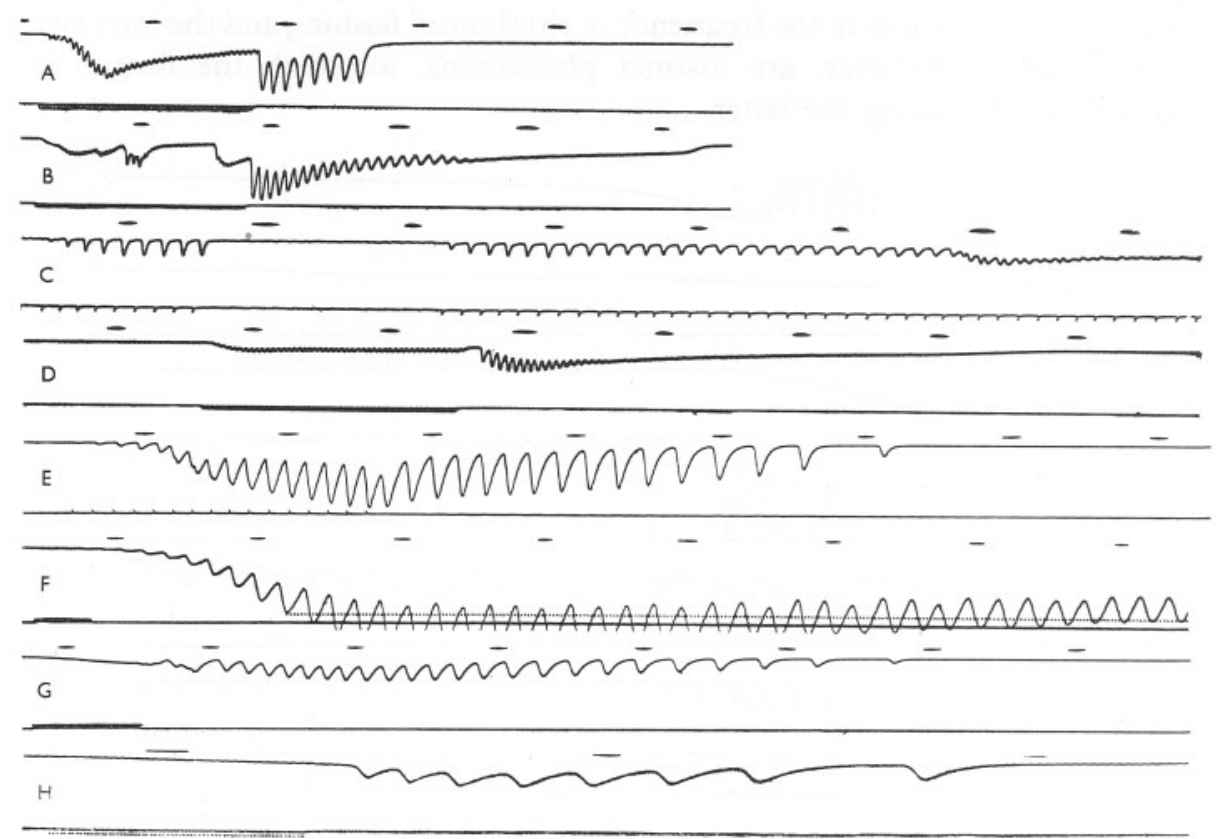

Fig. 4. A, B, luminescent flashes induced in isolated elytra of Polynoë by repetitive stimulation at $25 / \mathrm{sec}$. (A), and $42 / \mathrm{sec}$. (B). Time scale, I/sec. C, repeated flashes in isolated elytra of Lagisca which were stimulated at $8 / \mathrm{sec}$. (C), and $26 / \mathrm{sec}$. (D). Time scale, I/sec. E-H, luminescent responses of Gattyana elytra to repetitive stimulation. E, $8 / \mathrm{sec}$; F, 38/sec.; G, 66/sec.; H, I20/sec. Time scale above each record, I/sec.

40 msec. in Acholoë, it would be expected that a frequency of 25 or more impulses/sec. would be needed to bring about complete fusion of the separate responses.

These results, which were produced by repetitive stimulation, again can be compared with records of protracted rhythmical flashing induced by one or a few stimuli. When rhythmic flashing is occurring at a slow rate (up to about $5 / \mathrm{sec}$.), the separate responses are discrete and each one returns to base-line (zero intensity) (Fig. 3 A, B). When rhythmic flashing is taking place at higher rates than this, the separate flashes summate to various degrees, depending upon the intervals between consecutive flashes. For example, in 
Fig. 3C (Harmothoë), rhythmic flashing shows a frequency of $9 / \mathrm{sec}$. (interval IoO msec.), and there is a progressive build-up of intensity. Scales rarely flash rhythmically at a faster rate than this, which is insufficient to produce complete fusion.

If the frequency is gradually raised during a period of stimulation, the rate of flashing closely follows the rate of stimulation (Fig. 5A).

At high rates of stimulation the luminescent responses show irregularities in both frequency and amplitude. When the frequency is greater than $35 / \mathrm{sec}$., the scale may not respond to every stimulus, but may begin flashing at some rate slower than the frequency of stimulation. In Fig. 5B (interval $2 \mathrm{I} \mathrm{msec.),}$

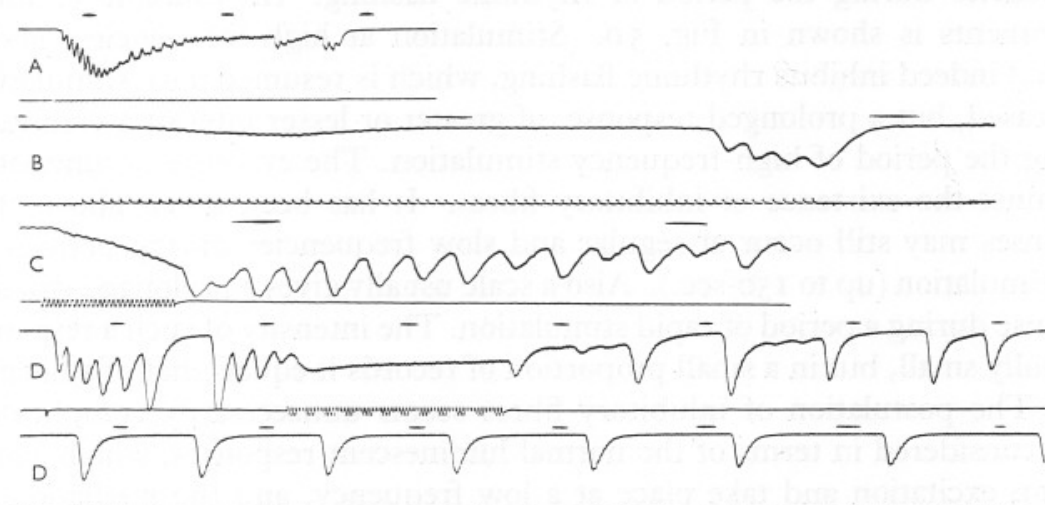

Fig. 5. A, increasing the frequency during a period of stimulation of the scale of Acholoë. The frequency of stimulation rises from an initial level of $28 / \mathrm{sec}$. to $42 / \mathrm{sec}$., and the flashes closely follow the rate of stimulation. Time scale above, I/sec. B, repetitive stimulation $(47 / \mathrm{sec}$.) of an elytrum of Acholoë. There is initially a small smooth response, lasting $0.8 \mathrm{sec}$., followed by 4 flashes at a slow rate independent of the rate of stimulation. Time marks above, I sec. intervals. C, stimulation of an elytrum of Acholoë by alternating current at a frequency of 100 cycles/sec. During stimulation the luminescent response shows a slow rise, followed by rhythmic flashing at a slow rate (Io/sec.) once electrical stimulation has ceased. Time marks above, I sec. interval. D, E, the effect of highfrequency stimulation on rhythmic flashing in an isolated elytrum of Acholoë. Rhythmic flashing was induced by a single impulse, and the scale was then stimulated by a burst of a.c. lasting $\mathrm{I} \cdot 6 \mathrm{sec}$. at a frequency of $50 \mathrm{cyc}$. $/ \mathrm{sec}$. Time scale above, $\mathrm{I} / \mathrm{sec}$.

-for example, the scale shows initially a small smooth response, but ultimately begins flashing at a slow rate, much below the frequency of stimulation. During stimulation the scale responds either by discrete flashes, or a prolonged glow, according to the frequency, but once the stimulation ceases, the scale may continue to respond by rhythmical flashes at a slow frequency (Figs. 3 G, I, 4A, B, E-H). That is, once the excitation at a fast rate is removed the now excited scale continues to respond normally at its own characteristic frequency. A third noteworthy feature is that the amplitude of the luminescent response is often small at higher frequencies of stimulation (either definite flashes or smooth response curve). Once stimulation has ceased, however, the 
continued rhythmic responses of the scale often proceed at a much greater amplitude (Figs. 3 G, 4A, B, F-H).

Several possible explanations can be advanced for these observations. The first is that stimulation at high frequencies produces polarization in the tissues, and is responsible for the small prolonged responses. This can be discounted since a.c. stimulation produces the same effects as condenser shocks (Fig. 5C). The second explanation is that the photocytes are supplied both by excitatory and inhibitory fibres, and that the effect of the latter predominates at high frequencies. This has been investigated by stimulating elytra into luminescence and then subjecting them to a short bursts of a.c. or condenser shocks at high frequencies during the period of rhythmic flashing. An example of these experiments is shown in Fig. 5D. Stimulation at high frequencies (above $50 / \mathrm{sec}$.) indeed inhibits rhythmic flashing, which is resumed once stimulation has ceased, but a prolonged response, of greater or lesser intensity, continues during the period of high-frequency stimulation. The evidence accumulated is against the existence of inhibitory fibres. It has been noted above that responses may still occur at regular and slow frequencies during periods of fast stimulation (up to $\mathrm{I} 5 \mathrm{O} / \mathrm{sec}$.). Also a scale usually gives a prolonged smooth response during a period of rapid stimulation. The intensity of such a response is usually small, but in a small proportion of records it equals that of a normal flash. The postulation of inhibitory fibres seems unnecessarily complicated when considered in terms of the normal luminescent responses, which occur only on excitation and take place at a low frequency, and the mediation of such responses is probably effected solely by impulses in excitatory nerve fibres.

It is probable that these results can be best explained on the basis of a refractory period, either of the efferent nerve fibres, or of the photocytes. The latent period of the luminescent response is of the order of $3 \mathrm{I}-2 \mathrm{I} \mathrm{msec}$. in Polynoë (Nicol, 1953), which includes the refractory period of the nerves. The refractory period of the luminescent response has been measured directly by arranging a Keith Lucas spring rheotome to deliver paired condenser shocks at suitable intervals. With this technique it has been determined that the refractory period lies between 9 and $16 \mathrm{msec}$., and a second impulse, falling within this interval, is ineffective. These figures give upper limits of 62-I Io stimuli/sec. at which nervous stimulation would still be effective. At high frequencies, when successive impulses fall within the refractory period of the nerve, it would be expected that every second or third or subsequent stimulus would be effective, but such form of response has only occasionally been recorded, and that irregularly (Figs. 3 H, 5B). Slight protracted responses (faint glow) have been obtained at frequencies as high as 150 pulses/sec., possibly resulting from some slight direct excitation of the photocytes, but actually the luminescent flashes usually show pronounced reduction in amplitude at frequencies from 20 to $40 / \mathrm{sec}$. A peculiar feature is that even the 
response to the first stimulus, at high frequencies, is minute. It appears, therefore, that some terminal mechanism is incapable of responding fully or is blocked at high frequencies, and this effect may occur either at the nervous terminals, or in the photocytes themselves. Without a new approach, and additional data, the problem cannot be pursued further.

\section{Interpretation of the Increment in Light Intensity}

It has been ascertained that an increase in light intensity occurs during repetitive stimulation or during spontaneously rhythmical flashing. During prolonged stimulation and rhythmic flickering, however, the individual flashes gradually decrease in intensity and this is ascribed in part to fatigue of luminescent ability. The question is now posed whether the initial increase in the intensity of successive light flashes is due to summation of effector responses, or to some elevation in the level of excitation which in turn controls the level of the effector response.

It has been noted above that under rapid stimulation, or during rapid rhythmic flashing, the separate responses may follow each other so quickly that a new flash may begin before the previous flash is extinguished and recovery of that flash is completed (e.g. Figs. $3 \mathrm{C}$ and $4 \mathrm{~A}$ ). If the successive responses were of equal magnitude and each response were superimposed on the preceding one before the latter had time to return to zero, then a gradual build-up in light intensity should result. A similar result should obtain even if successive responses are of decreasing amplitude, so long as each falls during the rising phase of the inflexion or the early period of decay of the preceding response curve. The arithmetic relations are sufficiently obvious not to need further elaboration. This will partly explain the progressive increment in light intensity which can be seen in many of the records.

In these records of repeated responses, however, it is apparent that another factor is operating in addition to summation of the light intensities of separate flashes. Often the response to the first stimulus is very small, and subsequent responses are many times greater than the initial response, and increase rapidly in magnitude. Also, the peaks of the first few responses may show a stepwise increase in intensity which is too great to be due entirely to partial summation of individual responses. When the light intensities of the first few responses are measured from the beginning of the inflexion to the peak of each flash, it is frequently found that a given response is greater than the one immediately preceding it.

When the responses are occurring at a slow rate (either rhythmic flashing, or as the result of continued stimulation at a low frequency), separate flashes may be observed, each of which decays to zero before another begins (Figs. I C, $\mathrm{D}, 3 \mathrm{~A}, \mathrm{~B}, \mathrm{D}, \mathrm{E})$. Under these conditions, as previously indicated, the initial few responses increase successively in height.

The relative amount of increment shown by successive responses varies 
considerably from specimen to specimen, and of course changes in the same specimen according to its physiological condition and the rate of flashing. When the initial response is large, the following responses increase gradually and progressively in height, but when the initial response is minute, then the increase of intensity in the succeeding first few responses is very striking (Figs. I C, D; 3A, B, D, E; 4E).

It is concluded from these results that each stimulus establishes a protracted state of facilitation, and, when the successive stimuli are arriving at suitable intervals, the corresponding facilitatory states are additive and heightened excitation results. This in turn controls the intensity of the response up to a certain limit determined by the physico-chemical conditions of the luminescent reaction. The effective duration of the facilitatory state is remarkably long, and it has been possible to characterize it as follows.

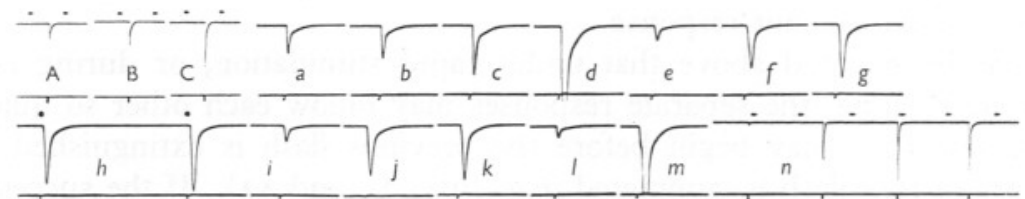

Fig. 6. A-C, single flashes from an elytrum of Polynoë stimulated at various intervals. Stimuli, single condenser shocks. A, initial flash; B, second flash after an interval of 4 min; $\mathrm{c}$, third flash after an interval of $3 \mathrm{~min}$. Time scale, I/sec. $a-n$, the effect of paired stimuli delivered at various intervals in scales of Polynoë which responded by giving a single flash per stimulus. Frames $a$ to $m$ from a single scale; $n$ from another scale. Time intervals between stimuli in consecutive frames as follows: $a-b, 2 \mathrm{~min}$; $b-c, \mathrm{I} \mathrm{min}$.; $c-d$, 30 sec.; $d-e, 2$ min.; $e-f$, I5 sec.; $f-g$, I5 sec.; $g-h$, I5 sec.; $h-i, 2$ min.; $i-j$, Io sec.; $j-k$, Io sec.; $k-l, 2$ min.; $l-m$, I min. The two stimuli in $h$ were separated by an interval of I sec.; the consecutive stimuli in $n$ were separated by intervals of $\mathrm{I} \cdot 5 \mathrm{sec}$. Time scale, I sec., for frames $a$ to $m$ shown in frame $h$; time scale for frame $n, \mathrm{I} / \mathrm{sec}$, above.

\section{Duration of the Facilitatory State of the Luminescent Response}

In a previous communication (Nicol, I953, fig. I2) it has been shown that the effect of a previous stimulus, as revealed in the increase of the light intensity of a succeeding flash, may last as long as $6 \mathrm{sec}$. in Acholoë. A detailed study of this phenomenon is documented in Fig. 6 from records of single flashes in Polynoë scolopendrina. In a fresh preparation subjected to repeated stimuli at various intervals, the effect of the first of two stimuli lasts as long as $4 \mathrm{~min}$. (Fig. $6 \mathrm{~A}-\mathrm{C}$ ). After this interval, a second stimulus gives a measurably larger response, amounting to an increment of $33 \%$ (Fig. 6B). When a scale has been repeatedly stimulated and fatigue sets in, the response elicited after several minutes shows no increment, or may even be slightly less than a previous flash (cf. $a, b$, and $d, e$, in Fig. 6). This could be due to fatigue in the system of neuro-effector transmission, but it is simpler to regard it, tentatively, as resulting from progressive exhaustion of luminescent material. The assumption is made that the intensity of a response is a function of the 
level of excitation and the quantity of luminescent material available in the photocytes. Since the residual facilitation after a protracted interval is small, the heightened response which it would be expected to provoke is cancelled by the concomitant decrease in luminescent material available for the manifestation of the response.

As the interval between two consecutive impulses is shortened, the second response increases relative to the first response in magnitude (Fig. 6, $b-k$ ). This is shown with special clarity in frame $n$ (stimulation interval, $\mathrm{I} \cdot 5 \mathrm{sec}$.). In the pair of records shown in frames $l$ and $m$, the second stimulus set off a double flash, with an interval of about $30 \mathrm{msec}$. between the two components, and with this interval the second peak of the double flash showed an

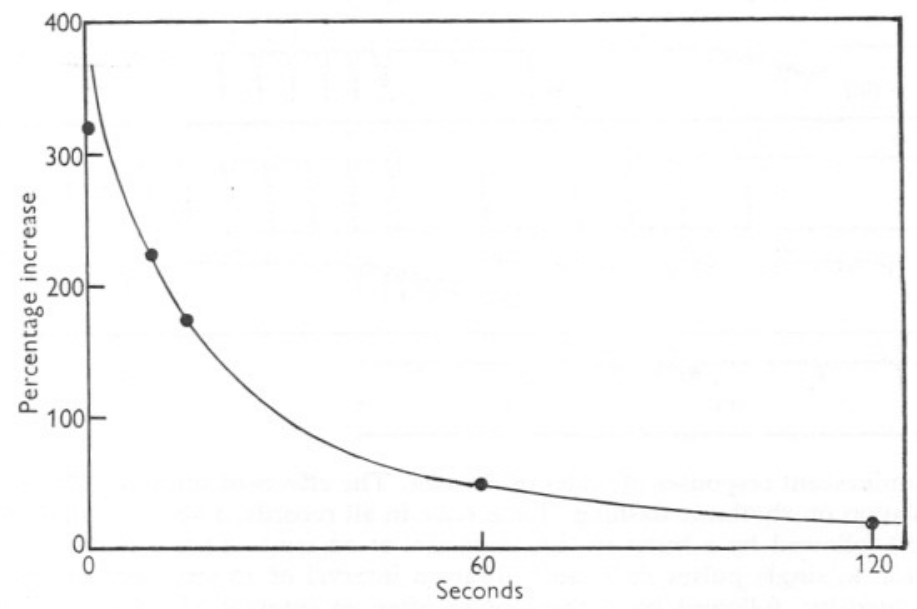

Fig. 7. A curve based on measurements of the light intensity produced by the second of a pair of flashes in a series in which the paired stimuli were delivered at varying intervals. Percentage increment in the intensity of the second response over the first is plotted against time between the two stimuli (sec.) Elytrum of Polynoë.

increment of over $300 \%$. Data from a scale have been plotted in Fig. 7, which shows that the excitatory effect of a previous stimulus decreases with time, and that the rate of decay of facilitation or excitation follows an exponential curve. If the material basis of this facilitation be thought of as a substance released or liberated at or in the effector cells by the arrival of a nervous impulse, then the curve of decay of facilitation shown in Fig. 7 suggests a simple monomolecular reaction effecting the removal of the substance concerned and converting it into an inactive form. On the same basis, the increment of excitation in successive responses, at brief intervals, as recorded by the rise in intensity of sequential flashes, would be due to gradual accumulation of an excitatory or complementary substance at a rate faster than it could be removed. 


\section{Rhythmic Flashing}

In very excitable preparations a single shock initiates prolonged rhythmic flashing (see Nicol, I953, for records of typical responses). Other scales give only a single flash per stimulus, and there are intermediate cases in which a single stimulus gives rise to a few flashes, or which require a number of impulses to start rhythmic flashing (Figs. I C, D; 3A, B, C).

From an examination of the many records collected from different animals, it became apparent that the onset and duration of rhythmic flashing are dependent on the previous history and the excitatory state of the scale. It also appeared that rhythmic flashing shows a condition of progressive fatigue akin to that revealed in diminution of intensity during the course of repeated flashing. An attempt has been made to analyse the factors involved as follows.

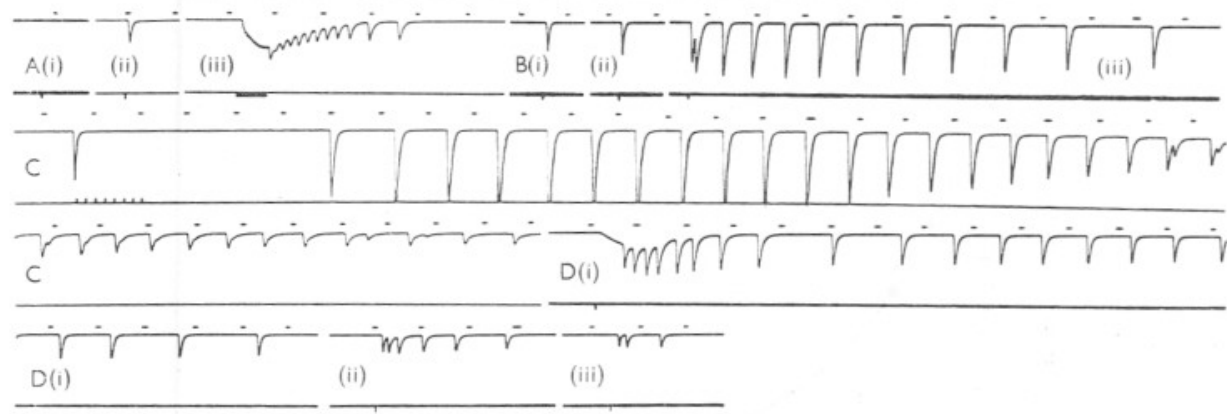

Fig. 8. Luminescent responses of scales of Acholoë. The effects of single stimuli and repeated stimulation on rhythmic flashing. Time scale in all records, $\mathrm{I} / \mathrm{sec}$. A, single pulses in (i) and (ii) followed by a burst in (iii) (0.75 sec. at $22 / \mathrm{sec}$.). I2 sec. between (i)-(ii), and (ii)-(iii). B, single pulses in (i) and (ii) at an interval of ro sec., showing increment in light intensity, followed by a third pulse after an interval of $\mathrm{I} \cdot 6 \mathrm{sec}$. in (iii), which resulted in prolonged rhythmic flashing. c, rhythmic flashing induced by a burst of impulses, with a pause of $5 \mathrm{sec}$. between the first and succeeding flashes. D, reduction in the number of flashes in consecutive periods of response. Stimulation, a single pulse in each of frames (i), (ii) and (iii).

In preparations which respond by rhythmic flashes, there are sometimes long intervals, extending to I 5 sec., between consecutive flashes or groups of flashes (Figs. 3D, E; 8C). In these cases the scale suddenly starts to flash rhythmically, often at a fast rate, several seconds after the response apparently has ceased. This indicates that the residual excitatory condition connected with the rhythmicity of the response can last for surprisingly long periods.

When a single pulse fails to evoke rhythmic flashing, several pulses or a burst of pulses will frequently do so. The excitatory condition responsible for rhythmic discharge, consequently, can be influenced by repetitive stimulation. The level of underlying excitation is augmented by repeated stimulation, resulting in an increase in the number of rhythmic flashes which occur after the stimulus or period of stimulation has terminated (Figs. I C, D; $8 \mathrm{~A}, \mathrm{~B}$ ). 
In an attempt to determine how long a stimulus will continue to influence the onset of rhythmic flashing, suitable scales were stimulated by pulses separated by intervals extending up to $2 \mathrm{~min}$. Rhythmic flashing was evoked by stimulating at frequencies as slow as I per I $2 \mathrm{sec}$. As noted above, rhythmic flashing has appeared spontaneously after quiescent periods of up to I5 sec. after a previous display has subsided. My data, therefore, set a limit of I2-I5 sec. for maximal duration of the effective excitatory state governing the onset of rhythmic flashing.

Finally, it has been observed that when a scale is stimulated on successive occasions into rhythmic flashing, each successive period of rhythmic flashing is of shorter duration, until eventually only one flash results from a stimulus, and a burst of impulses is then necessary to evoke a rhythmic discharge. A gradual fatigue or diminution of excitatory potentiality thus takes place with repetition, and this is manifested as a reduction in the number of flashes resulting from a single stimulus or given number of stimuli (Fig. 8D).

The presence of a ganglion in the elytrum suggested that this structure might be responsible for the rhythmic character of the flashing observed in severed scales. Experiments to test this hypothesis were carried out as follows. Elytra were narcotized with $\mathrm{MgCl}_{2}$, and were cut into two under a dissecting microscope in such a way that one half of each scale contained the elytrophore stalk and ganglion, and the other lacked this structure. The preparations were then washed out in sea water and the two halves of each scale were stimulated separately. Specimens of Acholoë and Polynö̈ were used in these experiments. With a long series of bisected scales it was observed that half scales containing a ganglion responded to a single shock by a series of rhythmic flashes or a single flash, whereas half scales lacking a ganglion never gave rhythmic flash responses (Fig. 9A). It is concluded that the elytral ganglion is involved in mediating the rhythmical flashing which is the characteristic response of normal elytra.

The occurrence of continued and rhythmic flashing long after the effective stimulus (tactile or electrical) has ceased denotes the existence of some repetitive excitatory mechanism governing its evocation. From several lines of evidence it is possible to cull the more likely explanations of this phenomenon, and to outline its main features. This evidence points towards repetitive discharge in nerve cells as the responsible factor involved.

Rhythmic flashing is not due to the recurrence of some excitatory condition at or in the peripheral effector cells for the following reasons. In the majority of records the flashes show great regularity in their timing and characteristics, each flash consisting of a smooth 'unimodal' curve, and subsequent flashes appearing at regular intervals. It seems highly improbable that a mass of isolated units (glandular cells) could maintain a rhythm of cyclical activity, as the result of an initial triggering stimulus, so as to produce such a series of 
discrete and uniform synchronous responses. The possibility of the light flash from one cell or group of cells affecting the others in turn, and so cyclically, is ruled out by the fact that the luminescent cells are not sensitive to illumination.

The crucial experiment consists of recording from fragments of elytra. As reported in the previous section, scale fragments lacking the ganglion give only a single flash to each electrical stimulus, whereas fragments containing the elytral ganglion flash rhythmically when subjected to a single stimulus. This ganglion lies in the centre of the elytrum and contains a number of nerve cells. It receives a nerve trunk from the elytrophore and gives rise to nerve fibres which radiate out over the elytrum and proceed to the photocytes.

Continued flashing might be due to repetitive firing in nerve fibres supplying the luminescent cells, but the fact that a fragment of a scale lacking the ganglion, but still retaining its peripheral nerve fibres, fails to flash repetitively, rules this out. The evidence thus implicates the ganglion cells in the control of rhythmic flashing.

Without some more direct method of recording, the exact mechanism must remain a subject for speculation. The rhythmic flashing may be due to regular oscillations in the excitatory state of nerve cells lying in the elytral ganglion. According to this hypothesis the excitatory oscillations would be initiated by some stimulus (electrical, nervous, mechanical), and nerve impulses would be generated in the efferent fibres at the excitatory peaks of the cycle. A second hypothesis assumes the existence of oscillatory nervous arcs whereby nervous impulses can continue firing in closed circumscribed circuits within the ganglion, and in this central locus each circular sweep of impulses fires the efferent nerve trunks. The process involves a very interesting instance of rhythmic nervous activity in a peripheral ganglion at a low phyletic level, and is worthy of further investigation.

The flashes often appear uniform enough to represent synchronous or nearly synchronous activation of all the photogenic cells in the scale. Occasionally there is a slight wobble in the response spikes which may represent slight differences in the timing of nervous impulses arriving in different regions of the scale. A uniform and regular pattern of flashing is the usual form of response in the scales of all species, but occasionally there is asymmetry in the pattern of rhythmic flashing. Sometimes there are alternate periods of strong and weak flashes, at other times the pattern is more irregular, with variable periods between spikes of different amplitude (Figs. 3D, E; 9B). It has been suggested previously that these asymmetrical responses are due to the separate activity of two or more neuro-effector units firing at different rates and acting out of phase, so that responses at one time are distinctly separable, and at others partially or wholly summated (Nicol, 1953). 


\section{The Effect of Drugs on the Luminescent Response}

Drug action has been explored in a number of luminescent species, and in view of the peculiar conditions of nervous regulation obtaining in the luminescent responses of polynoids, it seemed desirable to determine whether the action of certain drugs would throw any light on the processes involved. The following drugs were tested: adrenaline, acetylcholine, nicotine, eserine, atropine, curare, and strychnine. These had little or no effect on the luminescent responses of isolated scales, as the following summaries show.

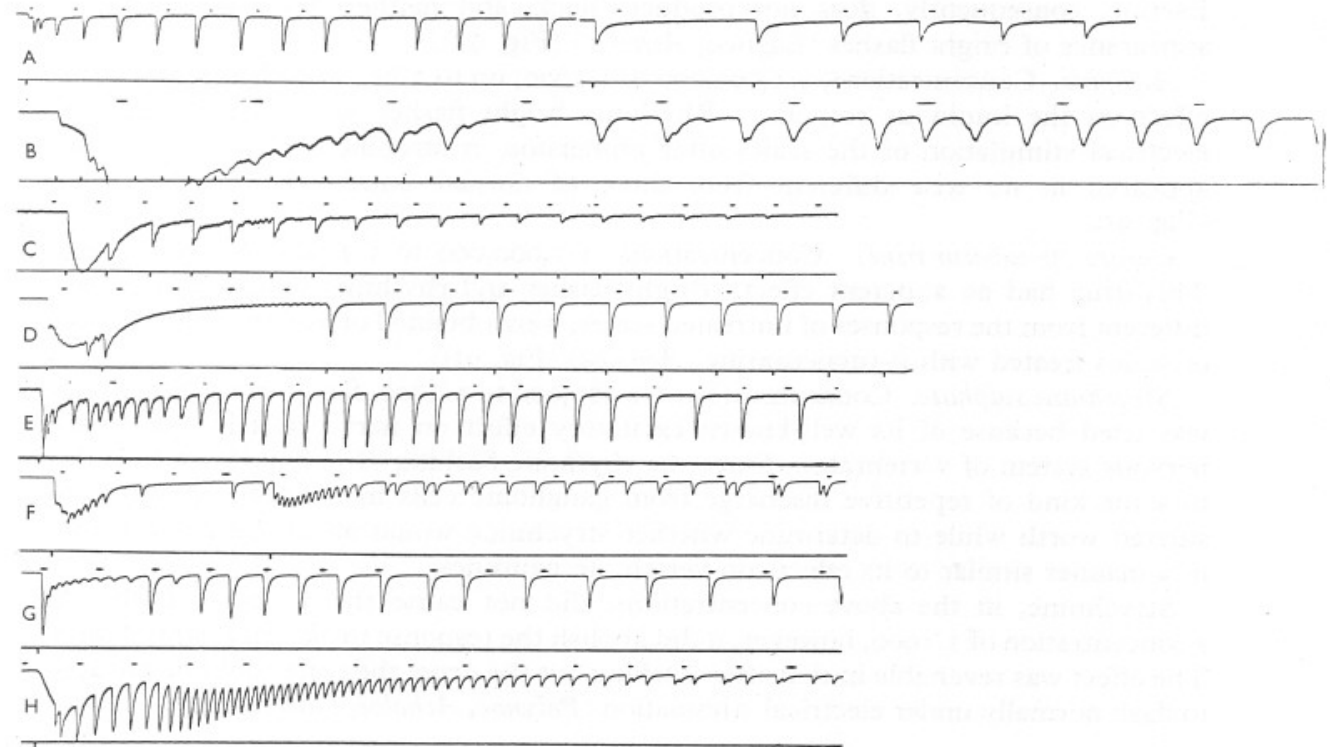

Fig. 9. A, stimulation of half scales of Acholoë. Left, rhythmic flashes in part of an elytrum containing a ganglion. Stimulation consisted of a single pulse. Right, single flashes, one per stimulus in the other portion of the same elytrum. Time scale, I/sec. B, rhythmic flashing induced in an elytrum of Acholoë by a burst of impulses. Time scale, I/sec. $\mathrm{C}-\mathrm{H}$, effects of drugs on the luminescent responses of isolated scales of Acholoë. Scales were immersed in solutions of the drugs for the times stated and then subjected to electrical stimulation (single or repeated shocks). Time scale, I/sec. C, adrenaline I/IO,000, $20 \mathrm{~min}$; D, acetylcholine I/I0,000, I20 min.; E, nicotine I/ $100,000,70 \mathrm{~min}$.; $\mathrm{F}$, eserine I/I00,000, $50 \mathrm{~min}$; $\mathrm{G}$, atropine $\mathrm{I} / \mathrm{I00}, 000,3 \mathrm{hr}$.; $\mathrm{H}, \mathrm{D}$-tubocurarine, $\mathrm{I} / \mathrm{I0}, 000$, $30 \mathrm{~min}$.

Adrenaline. Concentrations, I/I,000,000 to $\mathrm{I} / \mathrm{I} 0,000$ for $30-60 \mathrm{~min}$. This drug failed to excite isolated scales, and when treated scales were stimulated electrically, they still responded rhythmically and gave bright flashes very similar to those produced by normal untreated preparations (Acholoë) (Fig. 9C).

Acetylcholine. Concentrations, I/I,000,000 to I/I,000 for $\frac{1}{2}-2 \frac{1}{2} \mathrm{hr}$. Solutions of the highest concentrations were adjusted to $\mathrm{pH} 8.2$ with sodium acetate and sodium hydroxide. This drug failed to induce luminescence in isolated scales. At concentrations of I/I,000,000 to I/I0,000, scales still gave bright flashes and repetitive discharges when subjected to electrical stimulation, and the response recorded appeared normal 
when compared with those of untreated scales. At a concentration of $\mathrm{I} / \mathrm{ro00}$, some scales failed to respond, or gave reduced responses (Acholoë, Polynoë) (Fig. 9D).

Nicotine. Concentrations of $\mathrm{I} / \mathrm{I}, 000,000$ to $\mathrm{I} / \mathrm{I} 000$ for $30-75 \mathrm{~min}$. Scales did not flash when placed in solutions of nicotine. Electrical stimulation of treated scales produced responses, single bright flashes and rhythmic flashes, entirely similar to those of untreated scales (Acholoë, Lagisca) (Fig. 9E).

Eserine. Concentrations, I/I,000,000 to $\mathrm{I} / \mathrm{I0}, 000$ for $30-60 \mathrm{~min}$. Scales placed in solutions of eserine did not luminesce and electrical stimulation was employed to determine whether the drug had any effect on the characteristics of the response. At all strengths the scales still responded with bright flashes and rhythmic discharges. Eserine, consequently, does not produce block, and neither does it prevent the appearance of bright flashes (Lagisca, Acholoë) (Fig. 9F).

Atropine. Concentrations, I/I,000,000 to I/1000, up to $3 \mathrm{hr}$. This drug was without effect on the luminous response. Rhythmic bright flashes were still obtained on electrical stimulation of the scales after immersion in atropine solutions, and these appeared in no wise different from those of normal untreated scales (Acholoë) (Fig. 9G).

Curare (D-tubocurarine). Concentrations, I/I,000,000 to I/10,000 for 30-60 min. This drug had no apparent effect. Bright flashes and rhythmic flashing, in no way different from the responses of untreated scales, were obtained on electrical stimulation of scales treated with D-tubocurarine (Acholoë) (Fig. 9H).

Strychnine sulphate. Concentrations, $\mathrm{I} / \mathrm{I}, 000,000$ to $\mathrm{I} / \mathrm{I000}$, for $30 \mathrm{~min}$. Strychnine was tried because of its well-known excitatory effect on nerve cells in the central nervous system of vertebrates. Since the rhythmic flashing of polynoid scales is due to some kind of repetitive discharge from ganglionic cells in the scale, it was considered worth while to determine whether strychnine would affect these nerve cells in a manner similar to its effects on vertebrate neurones.

Strychnine, in the above concentrations, did not cause the scales to flash. At a concentration of $\mathrm{I} / \mathrm{IO00}$, however, it did abolish the response to electrical stimulation. The effect was reversible in that after washing out the drug, the scale could be induced to flash normally under electrical stimulation (Polynoë, Acholoë, Gattyana).

It is noteworthy that none of these drugs, with the exception of strychnine, was effective in abolishing the luminescent flashes which can be induced by electrical stimulation. Since the quick flash-response is due to nervous excitation, it seems reasonably certain that atropine and curare are unable to block neuro-glandular transmission in the scales of these animals. Neither acetylcholine nor adrenaline was effective in inducing a luminous response in the scales, and this would appear to exclude these substances as excitatory agents. Adrenaline is ruled out as an inhibitory agent since normal luminescent responses can still be elicited after its application; and there is no evidence that acetylcholine and eserine had any pronounced depolarizing action, in view of the quick flashes which attended electrical stimulation of scales which were treated with these substances. Strychnine, in high concentrations, is known to block axon conduction, and in the present experiments its inhibitory effect was probably achieved through this route (Heinbecker \& Bartley, I939; Coppée \& Coppée-Bolly, I94I).

The effect of pharmacological agents on luminescent tissues has been 
explored to only a very limited extent, and comparative data are fragmentary. Adrenaline fails to elicit luminescence in the polychaete Chaetopterus (Nicol, I952 a), and in the decapod crustacean Systellaspis (Harvey, I952). It apparently decreases the sensitivity to mechanical stimulation in the ctenophore Mnemiopsis (Chace, I94I). There is no evidence from any other source that adrenaline is normally produced in these animals, and this may be correlated with the absence of any pronounced physiological action. Chromaffine cells (believed to secrete adrenaline) have been described in the Aphroditidae (in Aphrodite aculeata), however, but the present evidence shows that adrenaline is not involved in the luminescent responses of polynoids (Gaskell, I9I4). In contrast, adrenaline forms a powerful stimulant to light production in fire-flies (Coleoptera). The action appears to be an indirect one, on the tracheae and cells, and not direct on the luminescent cells. In consequence, the tracheoles are dilated and the photogenic cells receive a greater supply of oxygen, which in turn regulates the oxidative luminescent process and the intensity of light emitted. Since adrenaline, so far as known, does not occur naturally in insects, this effect appears to depend on fortuitous sensitivity to adrenaline (Creighton, I926; Emerson \& Emerson, I94I).

Quite different is the situation in teleosts where adrenaline is normally produced by suprarenal tissue, and shows a sympatheticomimetic effect on many visceral activities (Nicol, I952c). Injections of adrenaline into Porichthys notatus and Echiostoma ctenobarba, two species of teleosts bearing photophores, cause them to luminesce (Greene \& Greene, 1924; Harvey, I93I, I952). This is suggestive evidence that adrenaline, which is a blood-borne hormone, may normally be involved as a chemical mediator as well in the luminescent response of these species. It is not unlikely that the serially arranged photophores in the head and trunk of teleosts are innervated by post-ganglionic neurones of the sympathetic nervous system, via recurrent grey rami, and cranial and spinal nerves. Branches of these nerves are known to innervate photophores in Argyropelecus and Lampanyctus, but fibre-pathways have not been worked out (Handrick, I90I; Ray, I950). At least the positive response to adrenaline suggests that nerve fibres supplying the photophores may be adrenergic in nature (Nicol, I952c).

Turning now to acetylcholine and other parasympatheticomimetic drugs, we find much less information available. Both acetylcholine and nicotine evoke luminescence in Chaetopterus, and the response to electrical stimulation is augmented by eserine (Nicol, I952 $a, b$ ). In Mnemiopsis, Chace (I94I) found that eserine increases the sensitivity to mechanical stimulation, and also increases the duration of the luminescent flashes. Acetylcholine, in high concentrations ( $\mathrm{I}$ in 3000), enhances this effect. Muscarine and pilocarpine ( $\mathrm{I} \%$ solutions in sea water) have a strong excitatory effect on the luminescent responses of Ophiopsila annulosa (Ophiuroidea). Atropine appears to have an inhibitory effect, as judged by responses to mechanical stimulation 
(Mangold, 1907). Luminescence in the millipede Luminodesmus sequoiae is not inhibited by curare, but there is no evidence that light production is under nervous control in this species (Davenport, Wootton \& Cushing, 1952). During a cruise on the R.R.S. Discovery II in I952, I have ascertained that neither Pelagia nor Systellaspis lights up after treatment with acetylcholine in various concentrations $\left(\mathrm{IO}^{-6}\right.$ to $\left.\mathrm{IO}^{-4}\right)$.

I have collected these scattered observations dealing with the effects of drugs on luminescent responses in order to expose any similarities and trends which may exist. There is obviously much variation in the effects of the several drugs listed above on different species. This is probably to be expected on several grounds. Luminescence, as one type or category of effector response, is often equated with others such as muscular contraction, chromatophore activity, glandular secretion, etc. The mechanisms of luminescence are markedly different in various species, however; indeed, several different mechanisms sometimes co-exist in the same species. In some species a luminescent secretion may be expelled, in others light is produced as the result of intracellular oxidative processes. In still other species the light is continuous, and muscular mechanisms or chromatophore-screens control the emission. With this heterogeneity of mechanisms it is not surprising that external agents should have extremely diversified effects on different luminous organisms. These several mechanisms are in turn regulated by the nervous system, and the details of innervation vary with the morphological complexity of the animal and the character of the tissue innervated. The effects of various pharmacological agents on the nervous systems of different animals are extremely varied, and this is reflected in the luminous responses. In evaluating the significance of drug action on the luminescent responses of any given species, it is advantageous to know the effects of a particular drug on other effector tissues and on the nervous system of that organism. Evidence from related fields of physiology and morphology may then indicate certain excitatory and effector processes which may be operative in the organism under. investigation, and which can be further tested in terms of the luminescent response. Investigations of this kind have rarely been attempted.

\section{The Effect of Cyanide}

Luminescence is basically an oxidative reaction, and depends on oxygen. For this reason the effect of cyanide, a respiratory inhibitor, was tried on isolated scales (Acholoë, Harmothoë). KCN, in concentration $0.000 \mathrm{I}$ M for $\mathrm{I} \mathrm{hr}$. failed to prevent luminescence following electrical stimulation. In concentration $0.00 \mathrm{I} \mathrm{M,} \mathrm{KCN}$ abolished luminescence in $45-60 \mathrm{~min}$. It seems probable, from the concentrations and times required to abolish the luminescent response, that $\mathrm{KCN}$ is acting by slow poisoning of efferent nerves. Cyanides, generally, have little effect on luminescent responses and reactions of animals (see Harvey, 1952). 


\section{The Effect of Unbalanced Salt Solutions}

In order to test the effect of different ions on the luminescent responses of polynoids, isolated scales were immersed in isosmotic solutions of selected salts. All experiments were carried out with scales of Lagisca, Acholoë, and Gattyana. At least four elytra were tested in each solution. The $\mathrm{pH}$ was adjusted to $8 \cdot 2$ with cresol red, unless otherwise stated.

Isotonic salt solutions having the following salt concentrations were used.

$\begin{array}{lclc} & \text { g. } / 1 . & & \text { g. } / 1 . \\ \mathrm{NaCl} & 3 \mathrm{I} \cdot 56 & \mathrm{MgCl}_{2} & 73 \cdot 20 \\ \mathrm{KCl} & 40 \cdot 26 & \mathrm{Choline} \text { chloride } & 65 \cdot 64 \\ \mathrm{CaCl}_{2} & 39 \cdot 95 & & \end{array}$

Freshwater. When dropped into distilled water, scales invariably luminesce. This takes the form of either a prolonged glow, or repeated flashing.

Solutions of simple salts

$\mathrm{KCl}$. Isosmotic solutions of $\mathrm{KCl}$ always produce a bright prolonged glow which persists until the scale is exhausted.

$\mathrm{NaCl}$. In solutions of isosmotic $\mathrm{NaCl}$, scales respond by slow or rapid repetitive flashes, which continue for some time and are followed by a steady glow.

$\mathrm{CaCl}_{2}$ ( $\mathrm{pH}_{7} \cdot 9-8 \cdot 2$ ). There is some doubt about the effect of this salt. In a few scales it evoked an initial brief flash, followed by repetitive flashing, but in the majority of scales its application was not attended by a luminescent response. It appeared to enhance the sensitivity of scales, however, since these were easily excited into luminescence by slight mechanical agitation after being placed in a solution of $\mathrm{CaCl}_{2}$.

$\mathrm{MgCl}_{2}$. No apparent effect.

Mixtures of isotonic salt solutions

The proportions of the different salt solutions are given in volumes.

$\mathrm{NaCl} 25+\mathrm{KCl} 0 \cdot 6$. Scales responded by rhythmic flashing.

$\mathrm{NaCl} 25+\mathrm{CaCl}_{2}$ I. No response observed.

$\mathrm{NaCl} 25+\mathrm{MgCl}_{2}$ 5. No response observed.

$\mathrm{NaCl} 25+\mathrm{KCl} 0 \cdot 6+\mathrm{CaCl}_{2}$ I. No response observed.

$\mathrm{NaCl} 25+\mathrm{KCl} 0 \cdot 6+\mathrm{MgCl}_{2}$ 5. No response observed.

$\mathrm{NaCl} 25+\mathrm{KCl} 0 \cdot 6+\mathrm{CaCl}_{2} \mathrm{I}+\mathrm{MgCl}_{2}$ 5. No response observed.

$\mathrm{KCl} 25+\mathrm{CaCl}_{2}$ ०.6. Scales responded by a bright prolonged glow.

$\mathrm{KCl} 25+\mathrm{MgCl}_{2}$ 5. Scales responded by a bright prolonged glow.

$\mathrm{KCl} 25+\mathrm{CaCl}_{2} \mathrm{O} \cdot 6+\mathrm{MgCl}_{2}$ 5. Scales responded by a bright prolonged glow.

$\mathrm{MgCl}_{2} 25+\mathrm{CaCl}_{2}$ I. No response.

Mixtures of isosmotic salt solutions and choline chloride

Choline chloride was employed as a physiologically inert substance to replace some one or other salts in the test solution.

Choline chloride. This substance by itself produced no luminescent response.

$\mathrm{NaCl} 75+$ choline chloride 25 . Scales flashed rhythmically in this solution.

$\mathrm{KCl} 2+$ choline chloride 98 . No response observed.

$\mathrm{KCl}$ ro + choline chloride 90 . Scales responded with a quick flash followed by a prolonged glow.

$\mathrm{CaCl}_{2} 3+$ choline chloride 97 . In some preparations occasional weak flashes were observed after a considerable interval, but the majority of scales gave no overt response. 
$\mathrm{NaCl} 75+\mathrm{KCl} 2+$ choline chloride 23. This solution evoked a few quick flashes followed by a prolonged glow.

$\mathrm{NaCl} 75+\mathrm{CaCl}_{2} 3+$ choline chloride 22. This solution evoked slow rhythmic flashing.

$\mathrm{NaCl} 75+\mathrm{MgCl}_{2} \mathrm{I}_{5}+$ choline chloride Io. No response observed.

$\mathrm{NaCl} \quad 75+\mathrm{CaCl}_{2} 3+\mathrm{MgCl}_{2}$ I5 + choline chloride 7 . No luminescent response observed.

$\mathrm{KCl} 2+\mathrm{CaCl}_{2} 3+$ choline chloride 95 . One scale out of six gave rhythmic flashes.

$\mathrm{KCl} 2+\mathrm{MgCl}_{2} \mathrm{I}_{5}+$ choline chloride 83. No response observed.

$\mathrm{KCl} 2+\mathrm{CaCl}_{2} 3+\mathrm{MgCl}_{2} \mathrm{I}_{5}+$ choline chloride 80. A faint persistent light was observed.

$\mathrm{NaCl} 75+\mathrm{KCl}_{2}+\mathrm{CaCl}_{2} 3+$ choline chloride 20. No light observed.

$\mathrm{NaCl} 75+\mathrm{KCl}_{2}+\mathrm{MgCl}_{2} \mathrm{I}_{5}+$ choline chloride 8. No light observed.

$\mathrm{CaCl}_{2} 3+\mathrm{MgCl}_{2} \mathrm{I}_{5}+$ choline chloride 82 . No observable response.

These responses may be summarized by observing that $\mathrm{KCl}$ in excess (4 g./1. or more) produces a prolonged steady glow; $\mathrm{NaCl}$ in amount equivalent to that occurring in sea water, evokes rhythmic flashing; $\mathrm{CaCl}_{2}$ has little effect by itself; and $\mathrm{MgCl}_{2}$ acts as an anaesthetic. In a mixture of $\mathrm{NaCl}$ and $\mathrm{KCl}$ the scales respond initially by rhythmic flashes and then give a prolonged glow. The addition of $\mathrm{Mg}$ abolishes the rhythmic flashing called forth by $\mathrm{Na}$, but not the prolonged glow due to $\mathrm{K}$. Ca likewise reduces or abolishes the effect of $\mathrm{Na}$, but not of $\mathrm{K}$, at least in excess. As is usually found in experiments of this kind, the addition of further ions restores the balance; thus, neither $\mathrm{Na}+\mathrm{K}+\mathrm{Ca}$ nor $\mathrm{Na}+\mathrm{K}+\mathrm{Mg}$ evokes a luminescent response.

The depressant effect of $\mathrm{Mg}$ on excitable tissues is well known, and its anaesthetic action calls for no further comment here. $\mathrm{Ca}$ and $\mathrm{Mg}$ individually, and together, act as ionic antagonists for $\mathrm{Na}$, and either opposes the excitable effects of $\mathrm{Na}+\mathrm{K}$. Antagonistic effects of this kind on excitable tissues have been frequently observed among marine invertebrates, and many examples can be found in research publications.

In an investigation of the effects of cations or combinations of cations, two apparent factors are involved, viz. the ability of the cations to excite tissues, and the ability to modify excitability as tested by stimulation. With the exception of $\mathrm{Mg}$ ion, only the former action has been tested in the present experiments. From the nature of the effects produced, certain conclusions can be drawn. K ion, in excess, is known to have a strong depolarizing effect on excitable tissue (nerve, muscle), and the prolonged glow which is the result of immersing elytra in an isosmotic solution of $\mathrm{K}$ is evidence of a direct depolarizing effect on the photocytes (Hodgkin \& Huxley, I945; Calma \& Wright, 1947). In effect, it is very similar to the bright prolonged response which follows strong stimulation of a scale, also ascribed to direct excitation of the luminescent cells.

Sodium ion also has a stimulatory effect on nerve, and its role in the transmission of the nervous impulse has recently been discussed by Hodgkin (I95I). 
In the present experiments it is noteworthy that $\mathrm{Na}$, initially at least, acts on the nerve and not directly on the photocytes, as revealed by the rhythmic discharge which its application elicits. The depolarizing action of $\mathrm{K}$ on the photocytes is antagonized by $\mathrm{Na}$, and these two ions together stimulate the efferent neurones, producing rhythmic discharge and flashing. Neither $\mathrm{Ca}$ nor $\mathrm{Mg}$, it may be noted, counteract the depolarizing effect of $\mathrm{K}(0.52-0.43 \mathrm{M})$ on the photocytes, but each is effective in reducing or preventing the stimulatory effect of $\mathrm{Na}$ ion on the efferent neurones supplying the photocytes.

Different cations have been tested on a variety of luminescent metazoans, and many scattered observations are now available, by no means easy to interpret. The scyphomedusan Pelagia noctiluca becomes luminescent in a solution of $\mathrm{KCl}$, and, on poisoning with $\mathrm{Ca}$, spontaneous luminescence appears over the whole surface. In the absence of $\mathrm{Mg}$, i.e. in a solution of $\mathrm{Na}, \mathrm{K}$ and $\mathrm{Ca}$, Pelagia passes into a state of hyperirritability, and flashes of light appear on the bell (Heymans \& Moore, I923, I924). The pennatulid Cavernularia habereri luminesces in isosmotic $\mathrm{KCl}$ but not in $\mathrm{NaCl}$. Moreover, luminescence is evoked by all solutions containing $\mathrm{K}$, and combinations of $\mathrm{K}$ plus one, two, or three other salts, viz. $\mathrm{NaCl}, \mathrm{CaCl}_{2}$ and $\mathrm{MgCl}_{2}$. The other three ions, in the absence of $\mathrm{K}$, fail to induce luminescence. It is rather surprising that a solution containing $\mathrm{NaCl}+\mathrm{KCl}+\mathrm{CaCl}_{2}+\mathrm{MgCl}_{2}$ should evoke luminescence. Since equal quantities of isosmotic solutions of the four salts were used in making up the test solution, the resultant concentration of $\mathrm{K}$ would be $c$. I4 times that in sea water, and the excitatory effect produced could be ascribed to $\mathrm{K}$ in excess. Unfortunately, the hydrogen-ion concentrations of the salt solutions do not appear to have been regulated, and the relatively high acidities of the unbuffered salts may themselves have produced excitatory effects (King-Li-Pin, Tchang-Si, Tai-Lee \& Liu-Yu-Su, 1936). It is reasonable to conclude that $\mathrm{K}$ has a similar stimulatory effect on Cavernularia as on Pelagia, but whether on the nervous system, or directly on the photogenic cells, is unknown. The ctenophores Mnemiopsis and Beroë also luminesce when treated with isosmotic solutions of $\mathrm{KCl}$ and $\mathrm{CaCl}_{2}$, but not $\mathrm{NaCl}$ and $\mathrm{MgCl}_{2}$, results similar to those obtained with Pelagia (Moore, I925).

In Chaetopterus variopedatus, a luminescent polychaete, isosmotic $\mathrm{KCl}$ causes bright luminescence, and $\mathrm{NaCl}$, though still effective, produces a fainter glow. Chaetopterus is a species which discharges a luminescent secretion by some contractile process, and it is not unlikely that $\mathrm{K}$ produces its effect by exciting the glandular cells directly. In this animal $\mathrm{Ca}$ and $\mathrm{Mg}$ fail to inhibit excitation by $\mathrm{K}$, but they reduce or abolish the stimulatory effect of $\mathrm{Na}$, possibly by blocking $\mathrm{Na}$ depolarization of efferent nerve fibres supplying the photocytes. When $\mathrm{Ca}$ or $\mathrm{Mg}$ is added to a solution of $\mathrm{NaCl}$ and $\mathrm{KCl}$, luminescence fails to appear, or is greatly reduced (Nicol, I952a).

Some additional data are available. Mangold (1907) observed that isolated spines of Ophiopsila annulosa will luminesce in strong $\mathrm{NaCl}$ solutions. Shöji 
(1919), who studied the effects of ions on the luminescence of the squid Watasenia scintillans, was concerned with the persistence of luminescence in the mantle-photophores, and retention of irritability to stimulation. His tables indicate that luminescence and irritability persist for about the same length of time in solutions of $\mathrm{NaCl}, \mathrm{KCl}$, and $\mathrm{CaCl}_{2}$, but several times longer in solutions of $\mathrm{MgCl}_{2}$. These solutions were osmotically equivalent to one another but only one half of the values for sea water $\left(\Delta-0.93^{\circ} \mathrm{C}\right.$.). It is not clear in these experiments to what extent the several ions initially excited luminescence. With combinations of salts it appears that $\mathrm{Mg}$ is most favourable for continued luminescence. Luminescence and irritability persisted longest in combinations lacking $\mathrm{Ca}$ (i.e. $\mathrm{Na}+\mathrm{K}+\mathrm{Mg}$ ). The photophores soon ceased to glow in isosmotic solutions containing $\mathrm{Ca}$ (i.e. $\mathrm{Na}+\mathrm{K}+\mathrm{Ca}$ ), but continued to respond to stimulation for long periods in balanced salt solutions $(\mathrm{Na}+\mathrm{K}+$ $\mathrm{Ca}+\mathrm{Mg})$ and in solutions lacking $\mathrm{Ca}(\mathrm{Na}+\mathrm{K}+\mathrm{Mg})$. Other experiments are shown in which different anions were tested. The results indicate that luminescence and irritability continue much longer in solutions of $\mathrm{Na}_{2} \mathrm{SO}_{4}$ and $\mathrm{MgSO}_{4}$ than in $\mathrm{NaCl}$ and $\mathrm{MgCl}_{2}$. These various results are rather puzzling but they show that the effects of different ions on the luminescent response are bound to be very complex. The persistence of luminescence and irritability in solutions of $\mathrm{MgCl}_{2}$ and $\mathrm{MgSO}_{4}$ for 3-4 hr. is extraordinary, in view of the general anaesthetic action of these salts on marine invertebrates. It is still uncertain whether squid photophores are subject to direct control, and these results may reveal only duration of vitality.

\section{Discussion AND CONCLUSIONS}

It appears to be firmly established from this and earlier studies that the luminescent responses of polynoids are under nervous control. The nerve fibres supplying the photocytes have been revealed by histological means, and their activity demonstrated by experimental methods. These nerve fibres are excitatory nerve fibres, and appear to be the only ones supplying the photocytes (Bonhomme, 1942; Nicol, 1953).

In the normal intact animal the chain of neural events leading to the appearance of luminous flashes appears to involve: excitation of peripheral receptors or sensory endings, which abound on the dorsal surface of the elytra, and are probably distributed over the general surface of the body as well; initiation of impulses in afferent fibres running into the nerve cord; reflex transmission of impulses in efferent fibres to a peripheral ganglion lying in the elytrum; relaying of nervous impulses into terminal efferent fibres which radiate outwards from the elytral ganglion to the photocytes (Pflugfelder, 1933; Bonhomme, 1942).

Some of the evidence for this reflex arc is indirect, but there seems little reason to doubt that it represents one method by which the luminescent 
response is evoked. When any localized region of the body is stimulated mechanically, luminescence appears not only in the elytra of the region directly stimulated, but in more distant segments as well. Excitation is thus initiated by peripheral stimulation, and is transmitted longitudinally along the nerve cord. Electrical stimulation of the nerve cord also evokes normal luminescent flashes.

Turning now to the efferent pathways, we find that the normal response of a scale is a long series of discrete rhythmic flashes. Evidence has been presented that flashing is controlled by a ganglion situated in the centre of the elytrum. In an entire scale, or portion of a scale containing the ganglion, a single shock sets the scale flashing, as the result of rhythmic discharge from the ganglion. It may well be that, in the intact animal, one or a few impulses are sent to the elytral ganglion from the nerve cord, and initiate rhythmic discharge and flashing. Of this we have no knowledge as yet.

A second method of stimulation, operating under natural conditions, is traumatic injury. Transection of the body evokes flashing posterior to the cut, but not anterior. I have previously hypothesized the existence of synaptic resistance in longitudinal pathways through the nerve cord to explain this phenomenon. Owing to the sensitivity of these animals and the ease with which luminosity is exhausted, it may prove difficult to get information on this problem.

Autotomy or removal of a scale also starts it flashing. Excitation follows from injury potentials established when the nerves are severed. Persistent discharge in nerves after injury is not unknown in other animals. It forms the basis of Parker's hypothesis concerning caudal bands in fish (Parker, I948). Adrian (I930) has demonstrated the occurrence of a persistent discharge of impulses in mammalian nerves after injury. The persistent discharges arise from the injured ends of the nerve fibres, the permanent depolarization of the injured region acting as a stimulus to the intact part of the fibre. The frequency of discharge is high, and the time relations indicate that the nerve fibres are responding to an excitation which outlasts the refractory period of the fibre; the refractory period thus determines the rate of discharge. There are several reasons for believing that the same process is not operating in autotomized polynoid elytra. First, rhythmical flashes (following electrical stimulation) can be induced only in a preparation containing a ganglion; bits of scale lacking a ganglion respond by a single flash to each stimulus. The ganglion, accordingly, is necessary for luminescence. Secondly, the rate of flashing is relatively slow, Io to I per sec., far below the rate which would be determined by the refractory period of nerve, if this were the controlling factor.

It seems that a stimulus, be it injurious, mechanical, nervous, or electrical, excites the pre-ganglionic nerve fibres ${ }^{1}$ and the nerve cells. A prolonged

1 There is no clear-cut evidence, as yet, for the existence of synapses in the elytral ganglion. T-shaped neurones, for example, could be involved. 
excitatory state is set up in the elytral ganglion, which far outlasts the duration of a single impulse, and is responsible for the initiation of impulses in the efferent fibres. These events are reflected in the luminous flashes which appear rhythmically for some time after stimulation. It appears as if the preganglionic stimulus, on exciting the ganglionic cells, sets up a rhythmic oscillatory state in the latter, with a rather slow period of discharge, beginning at about O.I sec. and increasing to I sec. Presumably at the peaks of the cycle, excitation rises to a sufficient level to fire the post-ganglionic fibres, and send off impulses to the photocytes.

A search of the literature reveals no strictly comparable system, although analogies exist. Rhythmic ganglionic discharges of an inherent nature have been recorded from the brain and nerve cord of different invertebrates (Bullock, I947), and occur in certain isolated peripheral ganglia, e.g. cardiac ganglion of Limulus (Armstrong, Maxfield, Prosser \& Schoepfle, I939; Bullock, Burr \& Nims, I943). A constant background of spontaneous discharge is characteristic of certain peripheral receptors, e.g. of vestibulo-lateralis system of fishes, and the frequency of such discharge may be rather low, around 5 impulses/sec. (Suckling \& Suckling, I950; Lowenstein \& Roberts, I950). Caudal photoreceptors have been identified in the nerve cord of the crayfish Cambarus, which discharge at a high frequency when illuminated. Of particular interest is the observation that after illumination ceases, an afterdischarge persists for several seconds, during which the impulses decline to a spontaneous level (Prosser, I934). Recordings from the isolated visceral ganglion of Aplysia have revealed the existence of spontaneous rhythmic oscillations of potential, arising in nerve cell bodies. These oscillations, followed by discharges in efferent nerves, show rather long periods, about $420 \mathrm{msec}$. (minima, $70 \mathrm{msec}$.) (Arvanitaki \& Cardot, I94I).

As the above résumé reveals, other instances are known in which rhythmic oscillations of potential, sometimes evoked by external stimulation, lead to nervous discharges, and the frequencies are often within the range encountered in polynoid flashing ( $\mathrm{I}-\mathrm{I} 5 / \mathrm{sec}$.). By postulating the occurrence in ganglionic neurones of rhythmic oscillations of potential corresponding to the rhythmic flashes, one can suggest explanations for certain characteristics of the rhythmic process. We have seen that long pauses, several seconds in duration and far exceeding the length of a normal period, sometimes intervene between successive trains of flashes (e.g. Fig. 8c). It is not unlikely that these quiet hiatuses indicate periods of subliminal potential oscillations, below the threshold for firing efferent fibres. Owing to the fact that the luminescent flashes show progressive fatigue leading to extinction, it is difficult to secure much information about the maximal duration of the underlying excitatory process responsible for the rhythmic flashes; certain favourable preparations suggest a maximal duration of $\mathrm{I}-2 \mathrm{~min}$. at least for supraliminal activity.

Curves showing variations in flash frequency with time and succession 
have been presented in a previous paper (Nicol, I953). The frequency is high at first, rapidly falls off to a steady level of approximately I/sec., and after a variable period, often about I min., decreases to extinction. Now if the time relations of this rhythmic flashing are a true index of underlying potential oscillations, then we can conclude that an external stimulus or nervous impulse excites the nerve cell bodies, and initiates rhythmical oscillations and discharge. At first high, the frequency of oscillation quickly falls off during the first few seconds. It has also been discovered that with repeated stimulation, the number of rhythmic flashes which can be induced by a single stimulus declines until finally only a single flash is induced by one stimulus. In the latter event rhythmic flashing can be evoked again by delivering a burst of high frequency pulses. It appears as if the excitatory state of the neurones is itself subject to fatigue. After repeated periods of stimulation the number of rhythmic oscillations falls off as well, until only a single discharge is evoked. These speculative remarks indicate the need for electronic recording of action potentials.

Peripheral ganglia, associated with the appendages, have been described in other errant polychaetes. In Nereis (Nereidae) and Hermione (Aphroditidae), there are parapodial ganglia at the bases of the parapodia, and in the latter animal these connect with cirrus ganglia near the cirri. Sensory nerves and motor nerves to parapodial muscles pass to and from these centres (Schneider, I902; Hanström, I928). According to Maxwell (I897) the parapodial ganglia of Nereis act as local reflex centres for parapodial movements. It is possible that the elytral ganglia of polynoids are derived from parapodial or cirrus ganglia, such as those existing in Hermione.

The increase in height of subsequent luminescent responses indicates the existence of some facilitatory phenomenon. The progressive increment in intensity of consecutive responses is analogous to staircase in the vertebrate heart, or tension-rise in crustacean muscle. The prolonged facilitatory period, up to 4 min., would appear to preclude the operation of some persistent electrical potential. Neither is there any indication that chemical transmittersacetylcholine and adrenaline-are involved in the luminescent response. There is some evidence for the existence of cholinergic nerve fibres among annelids, however, with the distinct possibility that acetylcholine is concerned in neuromyal transmission (evidence reviewed by Prosser, 1950). Evidence also exists for sensitivity to adrenaline in a few species (earthworm gut, vascular system of the leech) (Gaskell, I9I4; Hanström, I939; Ambache, Dixon \& Wright, I945). The ineffectiveness of atropine and curare on the luminescent response offers no conclusive evidence, since these two drugs fail to block neuromyal transmission in some other annelids (Nicol, I952d).

It appears, then, that either nervous excitation of the luminescent gland cells is radically dissimilar from neuromyal transmission, or that the neuroglandular junction is inaccessible to the reagents used. Nachmansohn (I950) has 
developed a hypothesis of this kind to explain differences between the effectiveness of methylated quaternary ammonium salts and tertiary amines, e.g. eserine. It may be noted that Bonhomme (1942) has asserted that the nerve fibres supplying the photocytes of polynoid worms may penetrate into the glandular cells. In this event a post-synaptic membrane, comparable to that between nerve and muscle, would not exist, and the drugs would have no extracellular interface upon which to act. The existence of distinct microscopic granules of luminescent material in the cytoplasm of the photocytes must mean that these cellular inclusions are provided with distinct intracellular interfaces. It is tempting to regard these interfaces as the site of control of the luminescent flash, by ionic exchange, release of energy-bearing substance, or other mechanism. Facilitation, then, may represent changes at these loci. The influence of the ionic environment, particularly of changes in sodium and potassium, is described on pp. 243-6. ATP, which has a positive effect on the luminescent reaction of certain animals, fails to revive luminescence in extracts of polynoid scales after the initial glow has died away (see Appendix) (Harvey \& Haneda, I95I).

Luminescent responses, consisting of brief flashes, are recorded for other marine and terrestrial animals, and it is of interest to discover whether the same or similar regulating mechanisms may be operative in these animals. Certain calyptoblastic hydroids give off intermittent repeated flashes when mechanically stimulated, possibly representing repetitive discharge in the nerve net. Intermittent flashes are reported in nudibranch molluscs (Kaloplocamus, Plocamopterus), a pulmonate (Dyakia), euphausiids (Nyctiphanes), and decapod crustacea (Sergestes). The regulating mechanism in these animals has not been investigated. In cephalopods and fishes which give off discrete flashes the photophores are either innervated and subject to direct nervous control (myctophids or lantern-fish), or periodically uncovered by screening devices (fire-fly squid Watasenia; stomiatoid teleost Astronesthes). Rhythmic luminous responses (flashing) have been most studied in fire-flies (Lampyridae). In the majority of luminescent species the response takes the form of an intermittent glow, pulsation, or series of flashes. In Photuris pennsylvania, for example, males flash at a rate of about $3 / \mathrm{sec}$., and each flash normally appears as a symmetrical response, lasting around $0.15 \mathrm{sec}$., and rising to a peak in half that time. There is still some uncertainty how these flashes are controlled, but much suggestive evidence exists that flashing is regulated by provision of oxygen through tracheal end-cells (see Buck, I948, and Harvey, 1952, for review of literature). In Fig. Io some flash-curves are presented of different species under various conditions. Luminescent flashes appear to develop a little faster in polynoids than in Photuris, and to be of slightly shorter duration. An apparent difference between the flash-curves of the two animals lies in the symmetrical appearance of the curve for Photuris, and the slower progress of decay in the curve for Acholö. 
The symmetrical appearance of the response of Photuris (likened to a distribution curve) probably depends upon summation of the flashes of a great many sub-units, all slightly asynchronous, while the photocytes in each scale of Acholoe flash more synchronously. The decay portion of the curve (exponential) in the latter animal, therefore, more nearly represents the course of decay of the luminescent reaction in each photocyte. Added to Fig. Io are two curves for oxidation of Cypridina luciferin and luciferase, mixed prior to admission, and in the presence, of oxygen. In this animal, at least, interaction

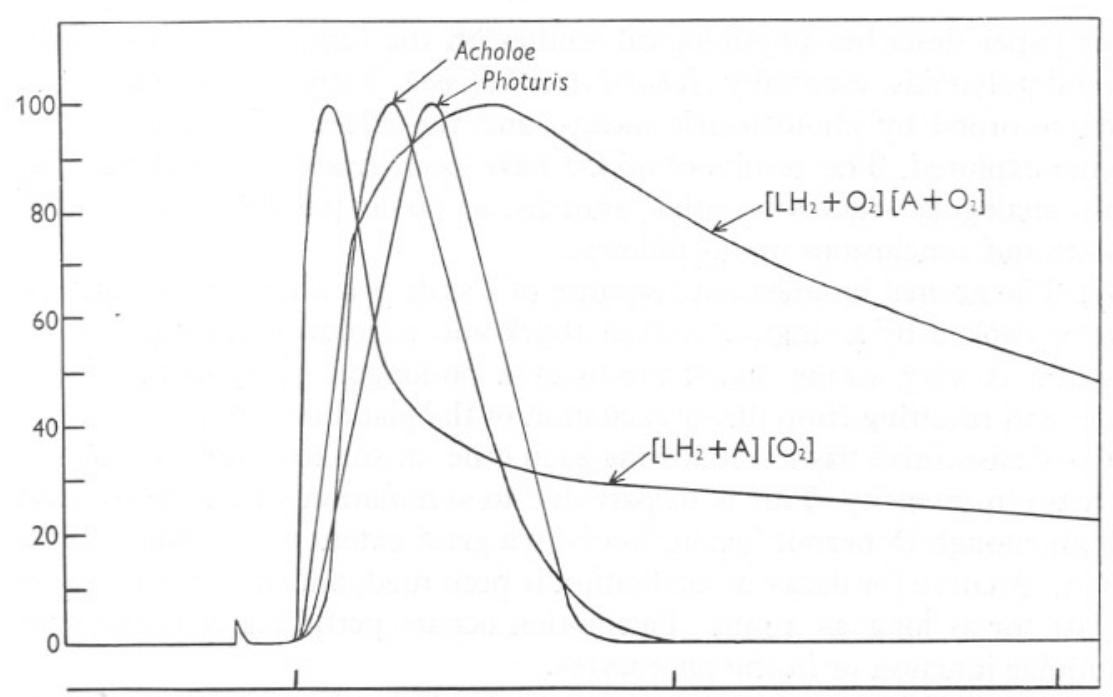

Fig. 1o. Curves of luminescent responses and luminescent reactions from various sources. Luminescent responses of Acholoë (polynoid) and Photuris (fire-fly). The small pip at the left on the base line is the stimulus mark for Acholoë only. Two curves are shown for oxidation of Cypridina luciferin. Luciferin and luciferase mixed in presence of $\mathrm{O}_{2}\left(\left[\mathrm{LH}_{2}+\mathrm{O}_{2}\right]\left[\mathrm{A}+\mathrm{O}_{2}\right]\right)$, and a mixture of luciferin and luciferase to which $\mathrm{O}_{2}$ is admitted $\left(\left[\mathrm{LH}_{2}+\mathrm{A}\right]\left[\mathrm{O}_{2}\right]\right)$. Time scale below, intervals of 100 msec.

between luminescent substrate and catalyst is a more limiting factor than oxygen availability. In intracellular luminescence (Polynoidae), the rise of intensity must represent the time course of provision of reactant(s), and interaction of reacting materials (Snell, I932; Chance, Harvey, Johnson \& Millikan, I940).

The luminescent responses of single scales of polynoids are usually simple flashes resulting from synchronous activity of all the photocytes, although a few records give evidence of asynchronous flashing of several units. From this it appears that a single neurone innervates all the photocytes (one neuroeffector unit) or, if more than one neurone is involved, that the several neurones show synchronous activity and fire in pace with each other. Asynchronous activity, occasionally recorded, confirms histological evidence that 
several neurones exist in the elytral ganglion. Synchronous activity possibly depends on interaction of cell potentials, such as takes place between contiguous nerves (Carcinus) or adjacent nerve cells (Aplysia) (Katz \& Schmitt, I940; Arvanitaki, 1942).

Part of the expenses incurred in this research was defrayed by a grant-in-aid of scientific investigations from the Royal Society.

\section{SUMMARY}

This paper describes physiological studies on the luminescent responses of several polynoids, especially Acholoë and Polynoë. Luminescent flashes have been recorded by photoelectric means, and the effects of various chemical agents explored. The results obtained have been related to, and integrated with, analogous studies on other animals, as far as possible. The principal results and conclusions are as follows.

(i) The normal luminescent response of a scale is a series of flashes, which can be evoked by a single electrical shock and is controlled by the nervous system. A very strong shock produces a prolonged glow, exhausting the scale, and resulting from direct excitation of the glandular cells.

(ii) Consecutive flashes, following each other at suitable intervals, show an increase in intensity. This is in part due to summation when the frequency is high enough to permit fusion, but is to a great extent attributable to facilitation. A curve for decay of facilitation is presented, and the effect is shown to last for as long as $4 \mathrm{~min}$. Facilitation occurs peripherally at the neuroglandular junction or in the photocytes.

(iii) At high frequencies, above $25 / \mathrm{sec}$., the flashes begin to fuse. A consequence of high-frequency stimulation is that the intensity of response is reduced, due to failure of transmission or to the existence of relative refractoriness peripherally.

(iv) Absolute refractory period (Polynoë) of the response lies between 9 and I6 msec.

(v) Rhythmic flashing is controlled by a peripheral ganglion in the elytrum, from which nerves radiate to the photocytes. Preparations lacking this ganglion give only a single flash to each stimulus.

(vi) At the beginning of a response the flash interval is small, around IOo msec.; this increases to I sec. during the course of a response; in some preparations long intervals, up to $15 \mathrm{sec}$. between successive flashes, have been noted. When preparations are subjected to consecutive periods of stimulation, the number of flashes evoked gradually falls off, suggesting fatigue of the neural mechanism regulating flashing.

(vii) Of a series of drugs tried, viz. adrenaline, acetylcholine, curarine, eserine, atropine, nicotine, and strychnine, all were without effect on flashing except the last, which blocked electrical excitation. 
(viii) Isosmotic solutions of single salts and combinations of salts had the following effects: potassium caused a prolonged glow; sodium evoked rhythmical flashing; calcium increased excitability; choline chloride was without effect; magnesium acted as an anaesthetic; calcium and magnesium antagonized the excitatory effect of sodium. Potassium is thought to act directly on the photocytes, sodium on the nerves at first, and then on the photocytes.

(ix) ATP is shown to be without effect on extracts of the luminous tissues of polynoids, Pholas and Polycirrus (Appendix A).

\section{REFERENCES}

AdRIAN, E. D., I930. The effects of injury on mammalian nerve fibres. Proc. roy. Soc., B, Vol. I06, pp. 596-6I7.

Ambache, N., Dixon, A. St J. \& Wright, E. A., I945. Some observations on the physiology and pharmacology of the nerve endings in the crop and gizzard of the earthworm. F. exp. Biol., Vol. 21, pp. 46-57.

Armstrong, F., Maxfield, M., Prosser, C. L. \& Schoepfle, G., I939. Analysis of the electrical discharge from the cardiac ganglion of Limulus. Biol. Bull., Wood's Hole, Vol. 77, p. 327.

ARVANITAKI, A., I942. Interactions électriques entre deux cellules nerveuses continguës. Arch. int. Physiol., T. 52, pp. 381-407.

ARVANITAKI, A. \& CARDot, H., I94I. Les caractéristiques de l'activité rythmique ganglionnaire 'spontanée' chez l'Aplysie. C.R. Soc. Biol., Paris, T. I35, pp. I207-II.

BonHomme, C., I942. Recherches sur l'histologie de l'appareil lumineux des Polynoïnés. Bull. Mus. océanogr. Monaco, No. 823.8 pp.

BuCK, J. B., I948. The anatomy and physiology of the light organ in fireflies. Ann. N.Y. Acad. Sci., Vol. 49, pp. 397-482.

Bullock, T. H., I947. Problems in invertebrate electrophysiology. Physiol. Rev., Vol. 27, pp. 643-64.

Bullock, T. H., BURR, H. S. \& Nims, L. F., I943. Electrical polarization of pacemaker neurones. F. Neurophysiol., Vol. 6, pp. 85-97.

CALMA, I. \& WRIGHT, S., I947. Effects of intrathecal injection of $\mathrm{KCl}$ and other solutions in cats. Excitatory action of $\mathrm{K}$ ions on posterior nerve root fibres. F. Physiol., Vol. ro6, pp. 21 I-35.

Carter, H. E. (Editor), I949. Biochemical Preparations. Vol. I. 76 pp. London.

CHACE, A. M., I94I. Observations on luminescence in Mnemiopsis. Biol. Bull., Wood's Hole, Vol. 81, pp. 296-7.

Chance, B., Harvey, E. N., Johnson, F. \& Millikan, G., I940. The kinetics of bioluminescent flashes. F. cell. comp. Physiol., Vol. 15, pp. 195-215.

Coppée, G. \& Coppée-Bolly, M. H., I94I. Effets de la strychnine sur le nerf isolé. Arch. int. Physiol., T. 51, pp. 97-I29.

Creighton, W. S., I926. The effect of adrenalin on the luminescence of fireflies. Science, Vol. 63, pp. 600-I.

Davenport, D., Wootton, D. M. \& Cushing, J. E., I952. The biology of the Sierra luminous millipede, Luminodesmus sequoiae, Loomis and Davenport. Biol. Bull., Wood's Hole, Vol. 102, pp. roo-ro.

Emerson, G. A. \& Emerson, M. J., I94I. Mechanism of the effect of epinephrine on bioluminescence of the firefly. Proc. Soc. exp. Biol., N.Y., Vol. 48, pp. 700-3. 
Gaskell, J. F., I9I4. The chromaffine system of annelids and the relation of this system to the contractile vascular system in the leech Hirudo medicinalis. Phil. Trans. B, Vol. 205, pp. I53-2II.

Greene, C. W. \& Greene, H. H., I924. Phosphorescence of Porichthys notatus, the California singing fish. Amer. F. Physiol., Vol. 70, pp. 500-6.

HANDRICK, K., I90I. Zur Kenntnis des Nervensystems und der Leuchtorgane des Argyropelecus hemigymmus. Zoologica, Stuttgart, Heft 32, 68 pp.

Hanström, B., 1928. Vergleichende Anatomie des Nervensystems der wirbellosen Tiere. 628 pp. Berlin.

- I939. Hormones in Invertebrates. $198 \mathrm{pp.} \mathrm{Oxford.}$

HaRvey, E. N., I93I. Stimulation by adrenalin of the luminescence of deep-sea fish. Zoologica, N.Y., Vol. I2, pp. 67-9.

- 1952. Bioluminescence. 649 pp. New York.

HARVEY, E. N. \& HANEDA, Y., I95I. Adenosine triphosphate and bioluminescence of various organisms. Arch. Biochem., Vol. 35, pp. 470-I.

HeInBECKeR, P. \& BARTLEy, S. H., I939. Manner of strychnine action on nervous system. Amer. F. Physiol., Vol. 125, pp. 172-87.

Heymans, C. \& Moore, A. R., I923. Action des ions sur la luminescence et les pulsations de Pelagia noctiluca. C.R. Soc. Biol., Paris, T. 89, pp. 430-2.

__ 1924. Luminescence in Pelagia noctiluca. F. gen. Physiol., Vol. 6, pp. $273-80$.

HodGKIn, A. L., I95I. The ionic basis of electrical activity in nerve and muscle. Biol. Rev., Vol. 26, pp. 339-409.

HoDGKIN, A. L. \& HuxLEY, A. F., I945. Resting and action potentials in single nerve fibres. F. Physiol., Vol. 104, pp. I76-95.

Katz, B. \& SchmitT, O. H., 1940. Electric interaction between two adjacent nerve fibres. F. Physiol., Vol. 97, pp. 47 I-88.

KING-Li-PIN, Tchang-SI, TAI-LeE \& LiU-YU-SU, 1936. Étude de la variation corporelle et de l'action des cations sur la photogénèse de Cavernularia habereri Moroff. Contr. Inst. Physiol. Acad. Peiping, Vol. 3, pp. 87-94.

Lowenstein, O. \& Roberts, T. D. M., I950. The equilibrium function of the otolith organs of the thornback ray (Raja clavata). F. Physiol., Vol. IIo, pp. 392-4I5.

Mangold, E., 1907. Leuchtende Schlangensterne und die Flimmerbewegung bei Ophiopsila. Pflüg. Arch. ges. Physiol., Bd. I18, pp. 613-40.

Maxwell, S. S., I897. Beiträge zur Gehirnphysiologie der Anneliden. Pflüg. Arch. ges. Physiol., Bd. 67, pp. 263-97.

MOORE, A. R., I925. Electrical stimulation of luminescence-a case of reversed Pflüger's law. Amer. F. Physiol., Vol. 72, p. 230.

Nachmansohn, D., 1950. Studies on permeability in relation to nerve function. I. Axonal conduction and synaptic transmission. In Metabolism and function: a collection of papers dedicated to Otto Meyerhof, pp. 78-95. London.

Nicol, J. A. C., I952a. Studies on Chaetopterus variopedatus (Renier). II. Nervous control of light production. F. Mar biol. Ass. U.K., Vol. 30, pp. 433-52.

- I952 b. Studies on Chaetopterus variopedatus (Renier). III. Factors affecting the light response. F. Mar. biol. Ass. U.K., Vol. 31, pp. II3-444.

— I 952 c. Autonomic nervous systems in lower chordates. Biol. Rev., Vol. 27, pp. I-49.

— I $1952 \mathrm{~d}$. Muscle activity and drug action in the body-wall of the sabellid worm Branchiomma vesiculosum (Montagu). Physiol. comp., Vol. 2, pp. 339-45.

I953. Luminescence in polynoid worms. F. Mar. biol. Ass. U.K., Vol. 32, pp. $65-84$. 
Parker, G. H., I948. Animal Colour Changes and their Neurohumours: a Survey of Investigations, 1910-1943. Cambridge University Press.

Pflugfelder, O., I933. Zur Histologie der Elytren der Aphroditiden. Z. wiss. Zool., Bd. I43, pp. 497-537.

Prosser, C. L., 1934. Action potentials in the nervous system of the crayfish. II. Response to illumination of the eye and caudal ganglion. F. cell. comp. Physiol., Vol. 4, pp. 363-77.

- 1950. Muscle and electric organs. Ch. I6 in Comparative Animal Physiology. London.

RAY, D. L., I950. The peripheral nervous system of Lampanyctus leucopsarus. F. Morph., Vol. 87, pp. 6I-I78.

SCHNEIDER, K. C., I902. Lehrbuch der vergleichenden Histologie der Tiere. Jena.

SHōjI, R., I919. A physiological study of the luminescence of Watasenia scintillans (Berry). Amer. F. Physiol., Vol. 47, pp. 534-57.

SNELL, P. A., 1932. The control of luminescence in the male lampyrid firefly, Photuris pennsylvanica, with special reference to the effect of oxygen tension on flashing. Fourn. cell. comp. Physiol., Vol. I, pp. 37-51.

Suckling, E. E. \& Suckling, J. A., I950. The electrical response of the lateral line system of fish to tone and other stimuli. F. gen. Physiol., Vol. 34, pp. I-8.

\section{APPENDIX \\ Effect of Adenosine Triphosphate on the Luminescence of Certain Marine Organisms}

Following the experiments of Harvey \& Haneda (I95I), I have tested the effects of adenosine triphosphate on luminescent extracts of several marine animals, viz. Pholas dactylus, Polycirrus caliendrum, Acholoë astericola and Polynoë scolopendrina. The luminescent tissues of these animals were ground up with sand in a little sea water (Io ml.), until the light disappeared. A solution of $5 \mathrm{mg}$. ATP was then added to this extract, or to the supernatant fluid after centrifugation. In none of these preparations did ATP revive luminescence.

I have to thank Dr G. Y. Kennedy of the Cancer Research Laboratory, University of Sheffield, for a sample of the barium salt of ATP. This was converted to the sodium salt by the procedure described in Carter (I942). 